\title{
Reasons of Stock Exchanges Collapse in Asia: A Study from China and Pakistan
}

\section{Kamran Najaf*}

Islamic Business and Finance, Riphah International University, Islamabad, Pakistan

${ }^{*}$ Corresponding author: Kamran Najaf, Islamic Business and Finance, Riphah International University, Islamabad, Pakistan, Tel: +92 51 111 510 510; E-mail: kamran.raco@gmail.com

Received date: November 08, 2017; Accepted date: November 21, 2017; Published date: November 28, 2017

Copyright: (c) 2017 Najaf K. This is an open-access article distributed under the terms of the Creative Commons Attribution License, which permits unrestricted use, distribution, and reproduction in any medium, provided the original author and source are credited.

\begin{abstract}
In current time, a worst economic disaster continues from developed countries like United States of America, United Kingdom and Denmark etc., penetrate to other the countries and leave a negative impact on financial intuitions of developing countries. This economic disaster is the first biggest disaster in the history since the recession of 1928s in Japan. The major objective of this research to portray the picture of the effect of current situation of world financial disaster on stock exchanges of Pakistan (PSE) and China (SSE). For this purpose, facts and figures are collected from July 2004 to 30 June 2017 KSE-100 and SSE-100 index, it shows stock markets' indicators of Pakistan and China respectively, are used to locate inconsistency, EGARCH model is used. This study unveils the negative shocks that have more prominent effect on the instability of Pakistan and China economy. These stock markets also faced persistent volatility clustering. In the current area, this financial disaster ended at adverse value of share and its payback and disturbs the Pakistani and China stock exchanges but this effect did not influence much to Shanghai stock exchange and other stock exchanges in China but there is no doubt these were shake by this market crutch.
\end{abstract}

Keywords: Instability; Pakistan Stock Exchange (PSE); Shanghai Stock Exchange (SSE)

\section{Introduction}

Economic cycle plays vital role in the country to transfer resources from the surpluses resources entities to lesser recourses entities investors. The function of stock markets is helpful to facilitate to loss making institutions, and facilitate to shake private institutes and allocation of risk. The functions of stock exchange are complex and therefore, we have to analysis in different ways of stock exchange markets.

The stock exchange fluctuates because of domestic and international incidents and response at once after incidences. Stock exchange is a measurement unit in itself and it directly correlate to regional, economic, political, domestics and international events either it is positive or negative events.

Internal or external factors add instability in stock market that create adverse influence on evaluation of its performance and shake the self-confidence of stakeholder who will be invest due to in financial crisis as instability in value impact on value of assets of the investors. Instability plays a vital role to make decisions to diversify in portfolio and prevarication strategy. Every now and then, consists of bigger adverse instability due to this shock force the investor to exit from the market. That's way; a query about the effect of main countrywide and/or worldwide adverse and/or positive impact on the stock markets has rationally been mentioned in financial text. Current worldwide financial disaster has a main chaos which penetrates in worldwide, no matter it is developed or emerging countries. These disasters were quite different from Asian financial disasters in 1997-98 and were more catching and in deep from Asian crisis. Most likely, it is the biggest disasters after recession in 1929-30s that has disturbed financial institutes. These disaster starts from United States in middle of 2007-08 because of subprime mortgage disasters and got momentum day by day. Developing countries also faced adverse results of such disasters and it will impact on their economy through trade and finance. Inflow of capital from developed countries to developing countries getting low since the start of this disaster. These disaster mainly impact on Foreign Direct Investment, portfolio of investment through financial institution and developing countries exports. Like other institution, world's stock exchange also influenced by this wave and will result in declining since the 2008-09. China and Pakistan are very influential and important countries in Asia. The objective of this study is to locate the influence of recent time global financial crunch on Pakistan stock Exchange of Pakistan and Shanghai Stock Exchange (SSE) of China in order to see which stock exchange was impacted more badly due to financial crisis. This study also demonstrates of indiscretion information in relation to both stock exchanges by using E-GARCH model. To meet these purposed we use data from January 2003 to August 2010 of these stock markets.

The rest of the paper is structured as follows. Review of relevant literature is presented in section II. Methodology and data issues are discussed at section III. Empirical results are given at section IV and last section contains concluding remarks.

\section{Literature Review}

This study has covered different aspects of the stock exchanges collapse. We evaluation it briefly, many research did on the instability of stock exchange alone with the impact of financial disaster on the stock exchange [1]. Traditional econometric models are heavily relay on the hypothesis figure. This assumption is known as homoscedasticity or homogeneity and this assumption is the focus of ARCH/GARCH models. How instability in economy due to inflow of 
Page 2 of 5

cash or financial crisis could be modeled, the answer to this problem is an $\mathrm{ARCH}$ (autoregressive conditional heteroscedasticity) process. ARCH models have been introduced to evaluate instability in stock markets.

The impact of different financial disaster during the last three decades on stock exchange marker had also been evaluated by different researchers [2]. Some of the research measured impact among different stock exchange markets as contagion in the wake of Asian financial disaster 1997-1998. This research makes sure that international crisis penetrate among stock markets.

During this research in order to find out the effect of Asian financial crisis 1997-1998 from pre and post financial crisis and found that during financial crisis 1997-1998, performance of the Asian stock exchange markets impaired out of which Hong Kong stock exchange market was the major victim [3].

Worldwide financial crisis that triggers from United States since 2007, it considered the world's biggest crisis after recession of 1930s [4]. Of course, these disasters also impact to world's stock exchange markets and negatively strike them. Taking into consideration this, few researches also evaluate the influence of this disaster on stock exchange markets. By using EGARCH model research the response of payback of investment in stock market and its instability in Japan stock market to this recent worldwide financial disaster. The outcome of the research showed that investment in stock exchange payback and its instability in Japan [5-8]. In contrary to this study, we took point for Japan stock exchange market with traditional statistical investigation for say; variance analysis, standard deviation and split the statistics into pre and post financial disaster tenure. This study empirically revealed that during the financial disaster tenure, instability in Japan stock exchange market improved [9]. We realized that during recent time financial disaster, stock exchange markets of Gulf countries cope with negative pressure but this stock exchange getting stronger and stronger with the passage of the time.

\section{Methodology}

To locate instability in stock exchange, we use the different tools as Autoregressive Conditional Heteroskedasticity (ARCH) such type of models is very popular in financial research [10-12]. It is an important tool which is not only supportive in finding reason of instability but also faces with the situation of unevenness statistics evaluation. Asymmetric/disorder impact demonstrate fluctuation in the stock market either positive shock of goods news or negative shock of bad news from the stock exchange markets or vice versa [13]. Therefore, this research also utilized these test to evaluating the effect of worldwide financial disaster on stock exchange payback on investment as well as instability of Pakistan and China stock exchange markets (Table 1).

\begin{tabular}{|l|l|l|}
\hline & PSE-Stock Return & SSE-Stock Return \\
\hline Mean & 0.00069 & 0.000917 \\
\hline Median & 0.001347 & 0.002083 \\
\hline Maximum & 0.11528 & 0.154911 \\
\hline Minimum & -0.10621 & -0.11937 \\
\hline Std. Dev. & 0.016644 & 0.017747 \\
\hline Skewness & -0.12358 & -0.29807 \\
\hline
\end{tabular}

\begin{tabular}{|l|l|l|}
\hline Kurtosis & 7.729935 & 10.19259 \\
\hline Jarque-Bera & 1767.563 & 4149.713 \\
\hline Prob. & 0.000 & 0.000 \\
\hline
\end{tabular}

Table 1: Stock Returns Statistics of PSE and SSE.

\section{Data}

We use daily data of KSE-100 index and SSE-100 index of Karachi and Shanghai stock exchange respectively for the period 1st January 2004 to 31st June 2017. Data from Pakistan stock exchange and Shanghai stock exchange consists of 1994 and 2013 daily notes respectively and for this research purposes data were collect from Pakistan and China stock exchange websites [14]. Stock exchange payback is measured as: $R_{t}=\ln P_{t}-\ln P_{t-1}$ (6)Where $R_{t}$ stands for stock exchange payback return on investment in stock, in represents natural $\log , \mathrm{P}_{\mathrm{t}}$ was stock market index at time $\mathrm{t}$ and $\mathrm{P}_{\mathrm{t}-1}$ was stock market index at time $\mathrm{t}-1$.

The purpose of this research is to locate the effect of developed countries on financial disaster on stock exchange markets of Pakistan and China, therefore, a hypothec variable was prepared which was as 1 for the period from January 2009 to June 2017 defined as financial disaster period other SSE 0 [15-18].

Negative effect of such disaster on the development of developed economies became visible since the year 2007-08 [19]. We unveiled that first downfall in the world stock exchange markets including London stock exchange (LIBOR) was observed in the month of January 2008-09 [20]. Furthermore, we also selected the same months while analyzing the impact of recent global financial disaster on the Japan Stock exchange (Nikkei Stock Exchange). Keeping in view the discussions, this study also used starting to locate crisis as January 2008-09 in America of Mortgage. In the January and February earlier month in 2010 economies started to recover from this largest disaster but then these stock exchange also faced 9/11 a terrorist attach.

Table 1 mention that PSE and SSE consist of the same similar trend and mostly these trends was similar features of financial crisis series. Meanwhile, stock exchanges were zero in value and difference between maximum and minimum was the same [21]. Standard deviations evaluated differences in stock exchange payback against the investment in both markets. The skewness of values holding negative signs which can verify that payback in both markets was negative [22]. It demonstrates that irregularity contains in both series. Kurtosis values was very great, which mentioned that the payback in both stock exchange follow ups and down. It described as that PSE and SSE cope up with small or large changes frequently. Regression analysis is also highly important which make sure that both the stock exchange was not normal $[23,24]$. To know further understanding about stock exchange market payback in these countries, graphs of these paybacks was prepared at Figures 1 and 2. Graphs also indicate that fluctuation consists in these countries as confirmed from statistical evaluation and inactivity of instability clustering dominates in the markets [25].

\section{Empirical Results}

To assemble the purpose of this research, we used EGARCH model tool which was relayed on dependent variables and differences in equations and in this model dependent variables equation was important due to its explanatory variables. 
Page 3 of 5

This equation was solved by ARMA, that's way, this research also focused on ARMA requirement with the help of correllogram (Auto Correction Function) of each payback of stock exchange and after that the implication of the ARMA representation for the purpose of parsimonious model. Inspite of this, other analytical tests tools were also measured to confirm the models of each stock exchange series. For stock exchange payback in case of PSE, dependent variables was based on ARMA $(1,1)$ along with a hypothec of CRISIS to detain the impact of worldwide financial disaster on stock exchange payback but for SSE's stock exchange payback case, this equation hold only $\mathrm{AR}(1)$ as information because MA(1) was less important for this case.

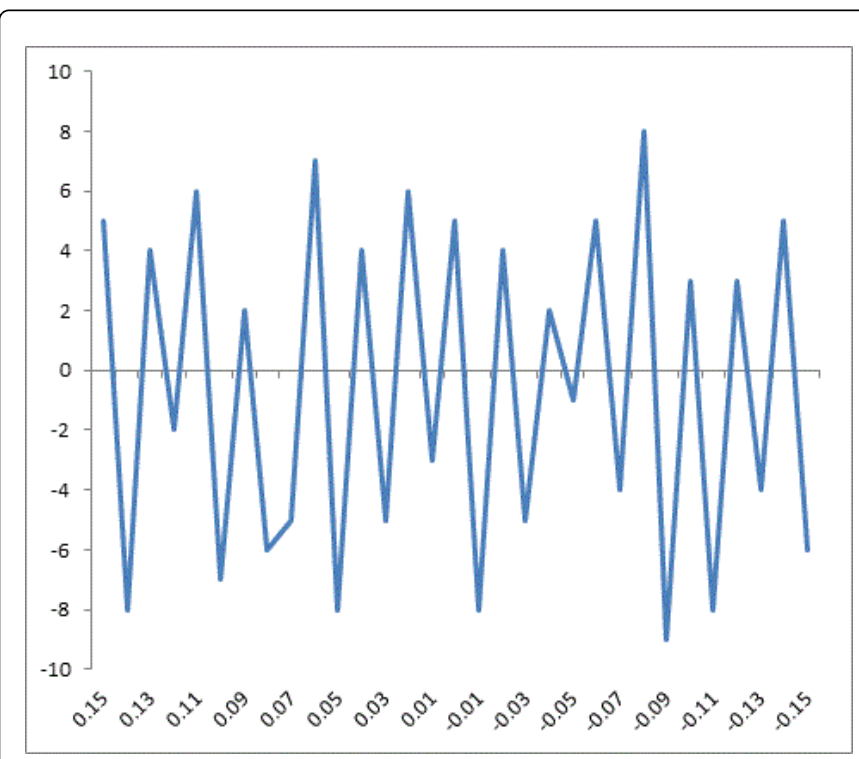

Figure 1: Stock returns of KSE.

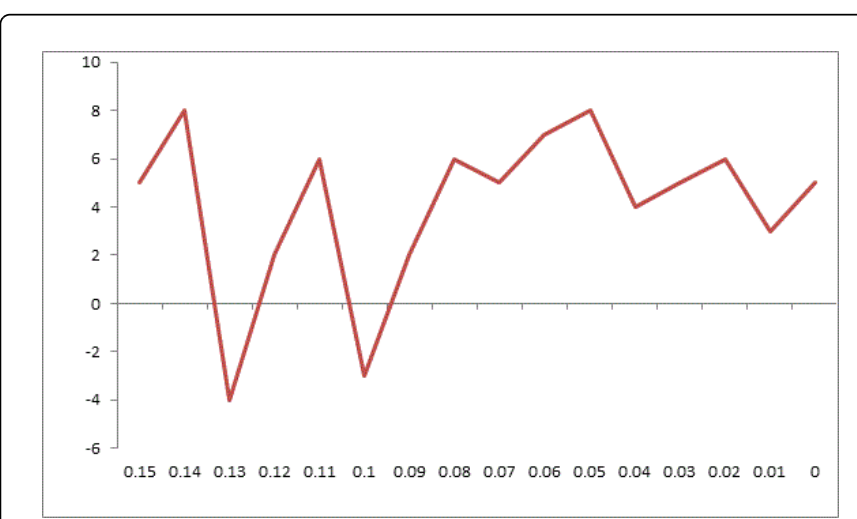

Figure 2: Stock returns of SSE.

Table 2 mentions that the results of EGARCH about the stock exchange payback returns of PSE and SSE. In first and second parts evaluation, the results of dependent variables and variance equations were denoted whereas bottom half of the part shows analytic outcome about the models.

\begin{tabular}{|l|l|l|}
\hline Variables & PSE & SSE \\
\hline Mean equation & & \\
\hline
\end{tabular}

\begin{tabular}{|c|c|c|}
\hline \multirow{2}{*}{ A } & $0.0021^{*}$ & $0.0016^{*}$ \\
\hline & -0.0006 & -0.004 \\
\hline \multirow{2}{*}{$\beta 1$} & $0.8778^{*}$ & $0.1270^{*}$ \\
\hline & -0.0556 & -0.0016 \\
\hline \multirow{2}{*}{$\beta 2$} & $-0.8268^{*}$ & - \\
\hline & -0.0677 & \\
\hline \multirow{2}{*}{$\Lambda$} & $-0.006^{*}$ & $-0.0027^{\star * *}$ \\
\hline & -0.0008 & -0.0015 \\
\hline \multicolumn{3}{|l|}{ Variance equation } \\
\hline \multirow{2}{*}{$\mu$} & $-1.3967^{*}$ & $-1.0037^{\star}$ \\
\hline & -0.0977 & -0.0986 \\
\hline \multirow{2}{*}{$\Delta$} & $0.8710^{*}$ & $0.9083^{*}$ \\
\hline & -0.0111 & -0.011 \\
\hline \multirow{2}{*}{$\Theta$} & $0.4017^{\star}$ & $0.2647^{*}$ \\
\hline & -0.0278 & -0.02456 \\
\hline \multirow{2}{*}{$\Gamma$} & $-0.0850^{*}$ & $-0.1436^{*}$ \\
\hline & -0.0194 & -0.0176 \\
\hline \multirow{2}{*}{$\Phi$} & $0.0362^{* *}$ & $0.1555^{*}$ \\
\hline & -0.016 & -0.0212 \\
\hline \multicolumn{3}{|l|}{ Diagnostic tests } \\
\hline F-Stat & $2.395^{\star *}$ & $2.410^{\star *}$ \\
\hline SIC & -5.656 & -5.645 \\
\hline Q-Stat (up to 36 lags) & All insignificant & All insignificant \\
\hline
\end{tabular}

Table 2: Results of EGARCH models.

Stock exchange payback forecast that the current stock payback by the coefficient of AR(1) was important. Coefficient of CRISIS shows the negative sign but its impacts ignorable which was only $0.3 \%$ is. It means there is very little effect of worldwide financial crisis on the stock exchange payback in Pakistan. In so far as dependent variable equation is value of $\delta$ mentions that the impact of previous variable on the exiting variable and denotes degree of instability of clustering. The value of coefficient was 0.871 and it is very significant which demonstrates that which determination instability of clustering dominated in PSE. This instability clustering demonstrates that once instability consists it took too long to settle. $Y$ value is important and it had negative sign which mentioned that irregularity information influence persists in this stock exchange and negative weave had more strong impact on the instability than positive shock. Coefficient of this model was correlated to demonstrate current financial crisis of the worldwide which was also important and has positive influence.

This evidence make sure that in current time financial disaster positively strike the instability of stock exchange payback by $4.7 \%$. The 
outcome from diagnostic tests was demonstrated in the below area of the table. The outcome mentioned, this model was free from autocorrelation due to Q-Stat values up to 36 lags were immaterial. Second model mentioned that the outcome regarding SSE which was mentioned in the previous column of Table 2. The outcomes of mean equation mentioned that Stock exchange market payback of SSE could be forecasted by the last day's payback due to the lag of stock exchange payback was very influent at $1 \%$ level. The coefficient of this financial crunch was very considerable at $10 \%$ level, it is also significant because has negative sign which demonstrated that there is easygoing hampering influence of financial crisis on stock exchange payback due to these financial crunch reduced only $0.21 \%$ payback. The outcome of dependent variance equation mentioned that lagged depended variance was very important and having 0.909 values which demonstrate high instability clustering contain in this stock exchange markets and instability took too much time to decompose. SSE also encountered asymmetric impact in instability of stock exchange payback.

The coefficient $\gamma$ was important with negative sign which mentioned that the chances of bad news were more obvious. The coefficient of financial crisis is also important with positive influence of instability. This showed us that recent time worldwide financial crunch increase $17 \%$ instability of stock exchange payback in China stock exchange markets. Evaluation of the outcome with Pakistani and China stock exchanges mentioned that both the stock exchange markets almost encounter the similar type of circumstances. Stock exchange payback of last days forecast present payback seeing that lagged value of payback was important and gives positive influence on current payback in these stock exchange markets. It was also released that leverage and asymmetric influence dominated which make sure that negative waves introduced become deeper impact than positive waves in these stock exchanges. Current global financial crunch was one the worst crunch in itself. This crunch hit stock exchange of both countries but the impact of crunch to China stock exchange is more powerful and stronger while evaluate to Pakistani stock exchange.

\section{Conclusion}

The major objective of this research was to discover the reaction of Pakistani and China stock exchange markets to worldwide financial crunch which happening from last half of 2008 got serious in 2008-09. This crunch happened in United States and after that it prevails in thunder to other countries. It is not only impact on developed countries, but also developing countries influence by this event which created changes in financial markets but also made huge impacts on economies of developing countries.

To evaluate the influence of this crunch on Pakistani and China stock exchange markets, we have utilized daily stock prices from January 2008 to August 2016 of Pakistan stock exchange and China stock exchange. Statistical analysis mentioned that stock exchange payback of the markets were not normally dispersed. EGARCH model was used for econometric study which illuminates that apathy of instability clustering dominate in the stock exchange markets of both countries. This inactivity claims that instability will take too long to become calm. Inspite that, both stock exchanges encounter irregularity rumors impact for say, bad news influence more and it create instability more than good news. Current financial crunch was result in negative major impact on stock exchange payback on stock. This crisis situation positively participate to instability in stock exchange payback of these stock markets but payback of these stock exchange of
China payback instability is more influenced by these crunch than Pakistan stock exchange. Major gap between Pakistani and China stock exchange, might be due to the numbers that China is a bigger economy than Pakistan and its stock exchange is wider than Pakistani stock exchange markets therefore the influence of global financial crunch is more active on China stock market.

\section{References}

1. Adamu A (2010) Global financial crisis and Nigerian stock market volatility. University of Jos, Nigeria 4: 154-167.

2. Alper CE, Yilmaz K (2004) Volatility and contagion: evidence from the Istanbul stock exchange. Econ Syst 28: 353-367.

3. Alsubaie A, Najand M (2009) Trading volume, time-varying conditional volatility and asymmetric volatility spill over in the Saudi stock market. J Multinational Finac Manage 19: 139-159.

4. Enders W (2004) Applied Econometric Time Series. Singapore: John Wiley \& Sons.

5. Engle RF (1982) Autoregressive conditional Heteroskedasticity with estimates of the variance of UK. inflation. Econometrica 50: 987-1008.

6. Enisan AA, Olufisayo AO (2009) Stock market development and economic growth: Evidence from seven Sub-Sahara African countries. J Econom Bus 61: 162-171.

7. Gupta R, Basu PK (2007) Weak form efficiency in China stock markets. Intl Bus Econom Res J 6: 57-64.

8. Hameed A, Ashraf H (2006) Stock market volatility and weak-form efficiency: Evidence from an emerging market. The Pakistan Develop Rev 45: $1029-1040$

9. Hussain F (1998) A seasonality in the Pakistani equity market: the Ramadhan effect. The Pakistan Develop Rev 37: 77-81.

10. Iqbal BA (2010) Global financial crisis: causes, emerging trends and strategy. Bus Rev 5: 35-50.

11. Javed A, Ahmed A (1999) The response of Karachi stock exchange to nuclear detonation. The Pakistan Development Review 38: 777-786.

12. Kanas A (2002) Is exchange rate volatility influenced by stock return volatility? Evidence from the US, the UK and Japan. Appl Econom Letters 9: 501-503.

13. Levine R, Zervos S (1996) Stock market development and long run growth. The World Bank Economic Review 10: 323-339.

14. Levine R (2002) Bank-based or market-based financial systems: which is better? J Financ Intermediat 11: 398-428.

15. Lim KP, Brooks R, Kim JH (2008) Financial crisis and stock market efficiency: Empricial evidence from Asian countries. Intl Rev Financ Anal 17: 571-591.

16. Llanto GM, Badiola AR (2009) The impact of global financial crisis on rural and microfinance in Asia. Discussion Paper Series No.2009-24. Philippine Institute for Development Studies.

17. Miyakoshi T (2002) ARCH versus information-based variances: evidence from the Tokyo stock market. Japan and the World Economy 14: 215-231.

18. Nelson DB (1991) Conditional Heteroskedasticity in asset returns: A new approach. Econometrica 59: 347-370.

19. Nieuwerburgh SV, Buelens F, Cuyvers L (2006) Stock market development and economic growth in Belgium. Explorations in Econom History 43: 13-38.

20. Olowe RA (2009) Stock return, volatility and the global financial crisis in an emerging market: The Nigerian case. Intl Rev Bus Res Papers 5: 426-447.

21. Omet G, Khaswneh M, Khasawneh J (2002) Efficiency tests and volatility effects: evidence from the Jordanian stock market. Appl Econom Letters 9: 817-821.

22. Pyun CS, Lee SY, Nam K (2000) Volatility and information flows in emerging equity market: A case of the Korean stock exchange. Intl Rev Financ Anal 9: 405-420. 
Citation: Najaf K (2017) Reasons of Stock Exchanges Collapse in Asia: A Study from China and Pakistan. Bus Eco J 8: 327. doi: $10.4172 / 2151-6219.1000327$

Page 5 of 5

23. Ravichandran K, Maloain AM (2010) The global financial crisis and stock market linkages: Further evidence on GCC Market. J Money Invest Banking 16: 46-56.

25. Zaidi SA (2009) Issues in Pakistan's Economy. Karachi: Oxford University Press.

24. Usman M (2010) Global financial crisis: Its impact on developing countries and lessons for Pakistan. IPRI Journal 10: 93-118. 